\title{
emerald
}

\author{
Qualitative Market Re
}

\section{Higher Education: a once-in-a-lifetime purchase}

\begin{tabular}{|r|l|}
\hline Journal: & Qualitative Market Research \\
\hline Manuscript ID & QMR-12-2017-0169.R4 \\
\hline Manuscript Type: & Research Paper \\
\hline Keywords: & $\begin{array}{l}\text { once-in-a-lifetime, infrequent purchases, university selection, Higher } \\
\text { Education, international students, consumer purchase decision making }\end{array}$ \\
\hline \multicolumn{2}{|l}{} \\
\hline
\end{tabular}

SCHOLARONE ${ }^{\text {m }}$

Manuscripts 


\title{
Higher Education: a once-in-a-lifetime purchase
}

\begin{abstract}
Purpose - Drawing on infrequent purchase and university selection literature, this study aims to make theoretical contributions to the identification and comprehension of the 'once-in-alifetime purchase' (OILP) phenomenon.
\end{abstract}

Design/methodology/approach - Data derived from in-depth interviews with 34 Taiwanese and 11 Chinese students over two phases suggest that an OILP qualitatively differs from other purchases.

Findings - The principal traits of OILP are quadripartite in character: zero-repurchase intention; permanency of purchase; high social pressure; and extensive information search. The results contribute to theoretical understanding of the higher education (HE) sector as one type of OILP provider, and managerial implications are discussed specifically for HE institutions.

Practical implications - Marketing managers of HE institutions should be cognisant of the range of information collected by prospective OILP customers from a variety of different sources. Prospective students who are OILP customers perceive non-marketing information as more reliable than marketing promotional materials and will better assist them during their decision making.

Originality/value - The paper makes explicit theoretical and instrumental contributions to our identification and comprehension of the OILP phenomenon, shedding new light on studies of consumer purchase decision literature. It also extends previous understanding of HE marketing by showing that choosing an HE degree is, in fact, an OILP and, as such, requires a new way of approaching prospective students as consumers.

Keywords - once-in-a-lifetime; infrequent purchases; university selection; Higher Education; international students

Paper type - Research Paper 


\section{Introduction}

This study has the specific research aim of making a theoretical contribution to understand what underpins a 'once-in-a-lifetime purchase' (OILP), which is defined in this paper as a consumer's cognitive intent to make a not-to-be-repeated procurement. To date, whereas significant research has been undertaken with regard to infrequent purchases, scrutiny of OILP has not been the subject of empirical research. The notion of an OILP suggests that some services/products are not only infrequently purchased, but also procured with the intention of never repeating the purchase in that person's lifetime. The important aspect of the above is the notion of intent. Typically, OILPs are expensive and often aligned with important rites of passage or can occur at key turning points in an individual's life; for example, weddings, honeymoons, birthday festivities ('coming of age'), and religious celebrations (bar mitzvah and first communion rituals). Thus, pre-payment funeral plans, private schooling, and postgraduate courses of study are all examples of OILPs.

Income and class may be important determinants of some OILP products and services, yet irrelevant to others. For example, a round-the-world cruise on Cunard's Queen Mary 2 may be an OILP for many, whilst for some it might represent an infrequent, and, for a few, a possible frequent, purchase. On the other hand, the purchase of an engagement ring is a typical OILP, regardless of one's financial status. Nevertheless, a change in personal circumstances can result in an erstwhile OILP purchase being repeated: for instance, a repeat purchase of a wedding dress upon re-marriage.

Given the limited understanding of the notion of OILPs and the lack of research attention, this study proposes, therefore, to explore the OILP phenomenon further. By reviewing existing literature on a subject that has the closest proximity - infrequent purchases - and collecting primary interview data from consumers who have purchased and engaged in one type of OILP, an overseas postgraduate degree, we make the first attempt to crystallise the notion of OILP and highlight its theoretical implications.

In the context of Higher Education (hereafter HE), previous studies have examined its global commercialisation (Pucciarelli and Kaplan, 2016), the student experience of HE (Douglas et al., 2015), the student-as-consumer approach in HE (Bunce et al., 2017), as well as various factors that have an impact on students' university selection. For example, the student decision-making process (Chapman, 1981; Hossler et al., 1999; Kotler and Fox, 1985; 
Vrontis et al., 2007; Wilkins and Huisman, 2015), the choice criteria for university selection (Daily et al., 2010; Moogan and Baron, 2003; Soutar and Turner, 2002), study motivations (Ahmad and Buchanan, 2015; Maringe and Carter, 2007), and how demographic factors influence information searches, e.g. gender (Veloutsou et al., 2005), socio-economic status (Connor and Dewson, 2001; Hemsley-Brown and Oplatka, 2015), as well as prior school background (Connor et al., 1999).

Most scholars agree that prospective students undertake a complex decision-making process when selecting a university (Bonnema and Van der Waldt, 2008; Hemsley-Brown and Oplatka, 2015; Maringe, 2006; Moogan and Baron, 2003), especially when they are choosing an international degree to study. Nevertheless, they have not discussed from an OILP perspective that the majority of consumers would only intend to study an undergraduate and a postgraduate degree once in their lifetime, unless they are very much academically committed. Therefore, we argue that university degree selection is more than a highinvolvement (Mazzarol and Soutar, 2002) or infrequent (Phau and Poon, 2000; Vigneron and Johnson, 1999) purchase; it is an OILP, especially for international students who have to travel to a new host country for their studies.

OILPs are ais one unique type of infrequent purchases. Drawing on the infrequent purchase and university selection literature, as well as data collected through in-depth interviews with international students from Taiwan and China regarding their choice of studying a postgraduate degree in the UK, this study employs a grounded effort by making an initial attempt to develop explicit theoretical contributions to the identification and comprehension of the OILP phenomenon. This paper adds value to the body of literature on consumer purchase decisions by revealing the principal traits of OILP and their impact on consumer behaviour when choosing an OILP offering.

By using HE as a classic example of an OILP, this study revealsed how zero-repurchase intention leads to permanency of purchase in university selection, and how both zerorepurchase intention and permanency of purchase lead to high social pressure and extensive information search. The perspective of viewing HE services as an OILP extends previous understanding of HE marketing and offers a new way of approaching prospective students as consumers.

\section{Literature Review}




\subsection{Infrequent Purchases}

Previous studies have examined frequent consumer purchases that are commonly low involvement, impulsive and stimulated by consumer emotions (Babu and Shams, 2015; Mohan et al., 2013). However, less is known about infrequent purchases that are high involvement, complex in terms of consumer decision making and often highly rational (Martin et al., 2015; Vigneron and Johnson, 1999). The rational man theory assumes consumers are rational in their purchases, while others have argued that consumer purchases are far more complex, as emotions, consciousness and unconsciousness all shape not-sorational but possibly impulsive purchases (Nwankwo et al., 2014). Debates remain among scholars on the extent of and interplay between affect and cognition in consumer purchase decision making (Grundey, 2008; Nwankwo et al., 2014; Shiv and Fedorikhin,1999).

Purchase frequency has been discussed as one of the elements affecting consumers' and firms' decision making. According to Bunn (1993), there are various buying decision approaches, such as casual purchases, low priority rebuys and new tasks, which can be differentiated based on purchase importance, task uncertainty, extensiveness of choice, and perceived buyer power. Typically, infrequent purchases in decision-making terms are associated with high-risk and complex consumption choices and, therefore, demand high involvement from consumers (Andreassen and Lindestad, 1998; Mitchell, 1992; Peterson et al., 1997; Phau and Poon, 2000; Vigneron and Johnson, 1999). For example, purchasing a childcare service, such as choosing a nursery, day care, a baby sitter, or party planner, is considered a high-involvement and high-risk decision, as parents would normally take a personal interest in ensuring that the best decision is made for their children's well-being. Therefore, various alternatives are likely to be carefully considered and compared before making each decision.

Lack of familiarity with product/service characteristics is another aspect of infrequent decision making. However, although infrequent, consumers' product knowledge may have increased over time when it comes to making the same decision again. For example, when parents are purchasing a childcare service for their second child, product awareness, product knowledge and consumer confidence are likely to have increased due to prior consumer experience (Karimi et al., 2015) when compared with making the same decision for their first child. There is often a trade-off between price and other important decision variables 
(Vahidov and Ji, 2005). For example, consumers of infrequent purchases, such as buying a computer or a car, can be categorised into three consumer types by the level of price sensitivity: budget, value and luxury consumers (Vahidov and Ji, 2005). "Budget consumers" seek to minimise the price while compromising on other product features, such as quality, durability and additional services. "Luxury consumers", in contrast, look to maximising product quality while accepting a higher price. "Value consumers"' lie between the two extremes and tend to evaluate all product alternatives more carefully than the two consumer groups referred to earlier (Vahidov and $\mathrm{Ji}, 2005$ ).

Consumers often engage in extensive information searches during decision-making stages when making an infrequent purchase in order to ensure that the best decision is made, due to their lack of familiarity with product features, little prior product knowledge and limited product awareness regarding infrequent purchases. Table 1 presents a summary of the characteristics of infrequent purchases from the literature.

\section{[INSERT TABLE 1 HERE]}

According to Table 1, infrequent purchases are characterised in the literature by complex consumer decision making (Mitchell, 1992), high involvement (Vigneron and Johnson, 1999), high perceived risk (Mitchell, 1992), expensive purchases (Phau and Poon, 2000), intangible value propositions (Peterson et al., 1997), and a strong impact on the person's selfconcept (Vigneron and Johnson, 1999).

This study proposes a new type of consumer purchase, an OILP, that is extremely high involvement and happens once only in the life of the consumer. Through in-depth consumer narratives, this study examines consumers of a once-in-a-lifetime purchase in the context of international students' selection of a UK postgraduate degree. The findings of this study extend our understanding of consumer purchase types, contribute to the literature debate on rational versus emotional purchases, and reveal how consumers rationalise their OILP evaluation, while dealing with anxiety as well as complex emotions as a result of the high social pressures on OILPs.

Whereas the existing literature does not examine the phenomenon of OILP, significant research has been undertaken with regard to infrequent purchases. The proximate literature on infrequent purchase decisions provides a degree of context for this research. 


\subsection{Selection of an HE Degree}

There are differences in scholarly opinion with regard to students being seen as 'consumers' of HE services-(Col., 1994; Hill, 1995; Niment., 2016), with-concerns regardingen the use of marketing for Higher Education (Conway et al., 1994; Hill, 1995;

Nixon et al., 2016). One of the debates focuses on the purpose of HE institutions beingis to impart knowledge and skills, whereas the main objectivepurpose of marketing is to make a profit, which would seem to rendermakes marketing incompatible with the educational mission in HE. However, we agree with the literature that marketing deals with the concept of uncovering specific needs, followeding by anthe attempt to fulfil the-unmet needs (Joseph and Joseph, 1997). In other words, HE institutions should satisfy educational needs by the development of appropriate HE services, letting potential consumers know of service availability ${ }_{-}$and offering appropriate prices at the right time and place.

$\underline{\mathrm{UK} u N e v e r t h e l e s s, ~ u n i v e r s i t i e s ~ a r e ~ n o w ~ i n c r e a s i n g l y ~ o p e r a t i n g ~ l i k e ~ c o m m e r c i a l ~ o r g a n i s a t i o n s ~}$ (Pucciarelli and Kaplan, 2016), due to strong competition in the HE sector for student recruitment (Hemsley-Brown and Oplatka, 2006). HE institutions need, therefore, need to show how theirHE services can add value to society, as well as HE stakeholders, such as current students, alumni and parents (Woodall et al., 2014). In this paper, we focus on one primary type of HE customer - -prospective students - as we see students as consumers of HE services (Nixon et al., 2016) and intend to examine their university selection to understand the phenomenon of OILP. It is for this reason that we regardsee students as 'the terms-HE 'consumers' and 'students' are used interchangeably-in this paper.

Selection of universities by prospective students is characterised as high involvement, expensive and high risk (Mazzarol and Soutar, 2002). Compared with home-based students, international students' overseas university selection is particularly complex (Ahmad and Buchanan, 2015; Patterson et al., 1998; Soo and Elliott, 2010; Wilkins and Huisman, 2015), as the latter need to consider additional factors such as safety issues, cultural differences, cost, visa, entry requirements, university environment and quality of life when choosing an overseas university degree (Cubillo et al., 2006). Thus, both marketer-dominated and nonmarketer-dominated sources are often employed by students to assist their decision making. Marketer-dominated information sources include prospectuses (Harker et al., 2001; Wilkins and Huisman, 2015), university websites (Veloutsou et al., 2005), promotional videos 
(Armstrong and Lumsden, 1999), HE fairs (Moogan and Baron, 2003), campus visits (Redwood, 2000), open days (Wilkins and Huisman, 2015; Yost and Tucker, 1995) and educational agents (Yen et al., 2012), whilst non-marketer-dominated sources include the students' parents (Pimpa, 2004; Wilkins and Huisman, 2015), other family members (Binsardi and Ekwulugo, 2003), friends (Franklin, 1995) and teachers (Clarke and Brown, 1998; Wilkins and Huisman, 2015).

In addition, the literature suggests that league tables are one of the information sources that students use to inform their university selection (Broecke, 2015; Souto-Otero and Enders, 2017) and that the impact of league tables is stronger on more academically able students (Gibbons et al., 2015) who tend to apply to highly ranked universities (Hazelkorn, 2007). However, a recent study (Souto-Otero and Enders, 2017) found that for both academically able students as well as less academic-focused students, the impact of league tables is not as strong as expected, as other key choice criteria, such as the reputation of the institution, fee levels and quality of teaching, are seen more important by students than league tables alone.

\subsection{Consumer Post-Purchase Behaviour}

The literature on consumer post-purchase behaviour has examined various factors associated with either repeat purchases or brand-switching behaviour, such as customer satisfaction, customer expectation, and consumer emotion (Kumar et al., 2017; Santos and Boote, 2003). For example, Jones and Taylor (2018) investigate consumer responses to frontline employees' requests for positive post-purchase evaluations, explaining the mixed feelings of consumers in response to employees' requests in the post-purchase phase. On the other hand, consumer regret and extent of rumination are found to increase brand-switching intention (Bui et al., 2011).

Other studies on post-purchase behaviour have also evaluated the relationship between consumers' post-purchase and word-of-mouth (WOM) intention (Dellarocas and Narayan, 2006; Kuo et al., 2009). The literature agrees that customer satisfaction has a positive influence on post-purchase intention (Duarte et al., 2018; Kuo et al., 2009), while highly satisfied consumers are more likely than merely satisfied customers to repeat purchases, as well as to provide WOM recommendations to others (Harrison and Shaw, 2004). However, previous studies assume that consumers will repeat the purchase if they are satisfied with the products or services, which might not apply in the context of an OILP when consumers only 
attempt to study for a postgraduate degree once in their lifetime, unless they are academically committed. While consumers of an OILP will not repeat the purchase of an HE degree, the endorsements of satisfied alumni of their HE institutions are important influences that have an impact on the university selection of potential consumers.

In the field of alumni engagement in the HE context, only one studyexample was found in the literature (Stephenson and Yerger, 2014) was found, that examineding the effects of brand identification on alumni donation behaviours. The study (Stephenson and Yerger, 2014) showed that satisfaction and participation with student affairs at the stage of enrolled students were positively associated with students' brand identification towards the university. As a result, brand identification correlated with alumni choice to donate, an increased donation amount, and the number of donations. This化 finding indicates that HE institutions need to engage their current students when they are still enrolled atwith the university, in order to cultivate the relationship further with them-when they become alumni.

Although various studies have been discussed with regard to university selection, the existing literature has failed to acknowledge the OILP nature of HE, ignoring the way in which OILP influences students' decision making when choosing a degree.

\section{Research Method}

In this study, we focus on the purchase of an overseas postgraduate degree course as a typical example of an OILP because most consumers tend to study only one degree in their lives (unless they are academically committed). This is especially true for international students, when considering the amount of monetary cost and uncertainty involved in travelling to and living and studying in a new country (Soo and Elliott, 2010). This study collected data from Taiwanese and Chinese students regarding their choice of a UK postgraduate degree over two phases. Two phases of interviews were designed for data triangulation. The HE sector is fairly mature in Taiwan and China, since the pursuance of an overseas degree is very popular. Deeply embedded in Confucianism, education is highly valued in Taiwan and China (China Post, 2008). Chinese parents place great emphasis on their offspring's education and often work hard to ensure that their children attain a university degree. As a result, $96 \%$ of high school students in Taiwan will continue their studies at university (Clark, 2010). However, whilst the attainment of a first degree affords little differentiation or competitive advantage for gainful employment, a postgraduate degree - especially an overseas postgraduate degree - 
does. More specifically, postgraduates holding Western degrees, especially from leading Anglophone nations such as the UK, Australia, New Zealand, Canada and the USA, are valued and the attainment of these degrees is associated with proficiency in spoken and written English (China Post, 2009). Consequently, many Taiwanese and Chinese students are keen to acquire a Western postgraduate degree if this is financially feasible (British Council, 2008).

With the aim of making a contribution to theory (Lee and Greenley, 2008), this study adopts a theory-building qualitative methodology. Following a well-established and, arguably, primary mode of qualitative data collection, the focus of data collection was in-depth interviews. Burgess (1982, p. 107) explains that the aforementioned approach allows researchers, among others, to "open up new dimensions of a problem and to secure vivid, accurate inclusive accounts that are based on personal experience". The interview objectives of this study were to answer the following questions:

1. What types of products or services were considered by participants to be once-in-alifetime purchases? How do participants describe 'once-in-a-lifetime purchases'?

2. Is university selection behaviour seen by participants as a once-in-a-lifetime purchase? Why or why not?

3. How did participants use information sources to assist their university selection decision?

4. How did participants feel when they were collecting information in order to select one university at which to study in the UK?

5. What impact does studying a Master's degree in the UK bring to the life of the participants?

The interviews conducted for this study were semi-structured, as this framework helps the researcher to focus on interacting with the participants. In addition, the flexibility of semistructured interviews enables the researcher to remain responsive to participants (McIntosh and Morse, 2015). Participants were free to respond to the open-ended questions outlined in the interview objectives (see above), and the semi-structured interviews allowed the authors to expand core interview questions with participants. Participants were given sufficient time to share their personal experiences, and the authors did not interrupt unless the participant had moved to an area that was not relevant to the interview objectives. All interview 
questions were asked of all participants in the same order, and all data were analysed systematically item-by-item later.

\section{Phase One:}

In-depth one-to-one interviews were undertaken with 34 prospective Taiwanese students who had been approached whilst attending a British Higher Education fair in Taiwan. For reasons of confidentiality, participants are identified by numbers in this article. The interviews were arranged after their visit to the fair. Prior to their interviews, the participants were sent the research objectives by email, together with a list of possible interview questions, so that they could better understand the purpose of the study. Each interview lasted from 45 minutes to one hour. With the participants' permission, the data were recorded using digital voice recorders. The interviews were undertaken in Mandarin Chinese and subsequently translated by one of the authors from Mandarin into English. The transcripts were then checked by another Mandarin-speaking author to verify the accuracy of the translations.

Of the 34 participants, 19 were male and the remaining 15 were female. The participants were between 22 and 37 years old. The majority of the participants (59\%) noted that they received financial support from their family, whilst others were either self-funded or partially family/self-funded (see Appendix 1).

As is common in qualitative research, the data underwent a coding process. Although this is not a grounded theory study, the process of analysis is similar. As noted by Charmaz (1983, p. 186), codes are shorthand devices that enable qualitative data to be labelled, separated, and compiled. Strauss (1987, p. 25) suggested that "Many indicators (behavioural actions/events) are examined comparatively by the analyst who then 'codes' them, naming them as indicators of a class of events/behavioural actions".

Specifically, the verbatim transcripts were analysed following template analysis (TA) techniques in coding (King, 2004). TA is one type of thematic analysis and balances a relatively high degree of structure in the process of analysing textual data with the flexibility to adapt it to the needs of a particular study. It has mostly been used to analyse data from individual interviews. TA was conducted in this study, following a series of steps commonly used in thematic analysis, in order to check reliability and validity: 
1. The first task of the researcher was to read the participant narratives, to acquire a feeling for their ideas in order to understand them fully.

2. The next step required the researcher to identify key words and sentences relating to the phenomenon under study (see Exhibits presented in the paper).

3. The researcher then attempted to formulate meanings for each of these significant statements. This process was repeated and recurrent meaningful themes were clustered. These were validated by returning to the participants to check interpretation.

4. The researcher integrated the resulting themes into a rich description of the phenomenon under study (see Table 2 Coding Hierarchy).

5. The next step was to reduce these themes to an essential structure that offers an explanation of the consumer behaviour (see the Findings section for the four principal traits of OILP).

Based on the interactions between the original template derived from infrequent purchase literature and the actual data, a list of higher-order codes representing key themes that emerged from the data was organised (see Table 2).

\section{[INSERT TABLE 2 HERE]}

Phase Two:

To provide data triangulation and further validate the emerging themes, a second wave of data collection was conducted in the UK by undertaking 11 in-depth interviews with Chinese students who had just started a postgraduate business degree at one UK university and were at the end of their first semester. After explaining the research aim and purpose, only participants who exhibited a strong interest in the research topic took part in our study, as is common practice in interpretive research (Silverman, 2006). The Chinese participants consisted of five females and six males, aged from 22 to 30 years old (see Appendix 2). The interviews were conducted by the first author in Mandarin Chinese. Each interview lasted approximately 30 minutes.

Phase Two was designed in this study to triangulate data and provide further validation of the emerging themes which had been identified in the first wave of data collection. Therefore, more specific interview questions were asked in Phase Two, leading to slightly shorter interview times when compared with Phase One. The data collection in Phase Two stopped 
once data saturation was reached. As data saturation was achieved after interviewing 11 participants in Phase Two, the sample size of Phase Two was smaller than in Phase One.

With the participants' consent, the authors recorded all the interviews, thus providing the opportunity to transcribe and later analyse participants' statements and avoid any loss of information. The interviews were then translated by the second author into English for data analysis and interpretation.

Using the template derived from the first phase of interviews, the data were employed to help validate the distinctive characteristics that are specific to OILP. The data collected in the second phase revealed no new findings; instead, they reinforced existing themes. This suggests the collection of the qualitative data had reached a satisfactory level of saturation (Morse, 2000).

\section{Findings}

The research findings suggest that there is no significant difference in the responses between the Taiwanese and Chinese students regarding their views on choosing a UK postgraduate degree as an OILP decision. However, the authors do not claim that Taiwanese and Chinese students should be seen as a culturally and ethnically homogeneous consumer segment for other decisions. The research findings provide a theoretical insight in terms of a quadripartite theoretical framework vis-à-vis once-in-a-lifetime purchases. Analysis of the data revealed that the principal traits of OILP are as follows (see Exhibit 1 below):

- zero-repurchase intention (a process and experience that are not expected to be repeated);

- permanency of purchase (a purchase with a permanent impact);

- high social pressure (the influence of family and social networks on decision making); and

- extensive information search (recourse to a widespread information search from various sources over an extensive period of time). 


\section{Exhibit 1: Traits of an OILP}

\subsection{Zero-Repurchase Intention}

The data clearly revealed that participants regarded the 'purchase' of a course of study leading to a UK higher degree as an OILP. The factors that made this so included the high cost; a further HE qualification was deemed unnecessary; and (related to the first) the degree was a means of securing employment. See Exhibit 2 for indicative quotations from the data.

\begin{tabular}{|l|l|l|}
\hline \multicolumn{2}{|l|}{ Exhibit 2: Zero-repurchase intention } \\
\hline $\begin{array}{l}\text { High cost - } \\
\text { cannot afford } \\
\text { it again }\end{array}$ & $\begin{array}{l}\text { Student } \\
14\end{array}$ & $\begin{array}{l}\text { From my observations of friends who had studied abroad, a UK } \\
\text { HE degree is really not cheap! I have to ask my parents for } \\
\text { support ... I don't think I could afford to do it ever again... }\end{array}$ \\
\cline { 2 - 3 } & $\begin{array}{l}\text { Student } \\
37\end{array}$ & $\begin{array}{l}\text { No other purchases in life are like studying a Master's degree... } \\
\text { I need to spend time and money on it, and it cannot be } \\
\text { considered as an enjoyable consumption experience because I } \\
\text { also need to work hard to get the degree! I definitely want to do } \\
\text { it only once in life... }\end{array}$ \\
\cline { 2 - 4 } & $\begin{array}{l}\text { Student } \\
45\end{array}$ & $\begin{array}{l}\text { I was very worried when I was deciding where to enrol... this is } \\
\text { a lot of money to spend from my parents. I don't want to waste } \\
\text { their money and I certainly cannot afford it again... }\end{array}$ \\
\hline $\begin{array}{l}\text { Unnecessary } \\
\text { because one is } \\
\text { plenty }\end{array}$ & $\begin{array}{l}\text { Student } \\
20\end{array}$ & $\begin{array}{l}\text { I don't think I will ever consider doing another overseas HE } \\
\text { degree again... Why would you want to do it again? It is very } \\
\text { expensive and time-consuming. I will have to leave my family } \\
\text { and friends behind for a long period! When I finish this degree, } \\
\text { I just want to get on the career ladder instead. }\end{array}$ \\
\hline
\end{tabular}




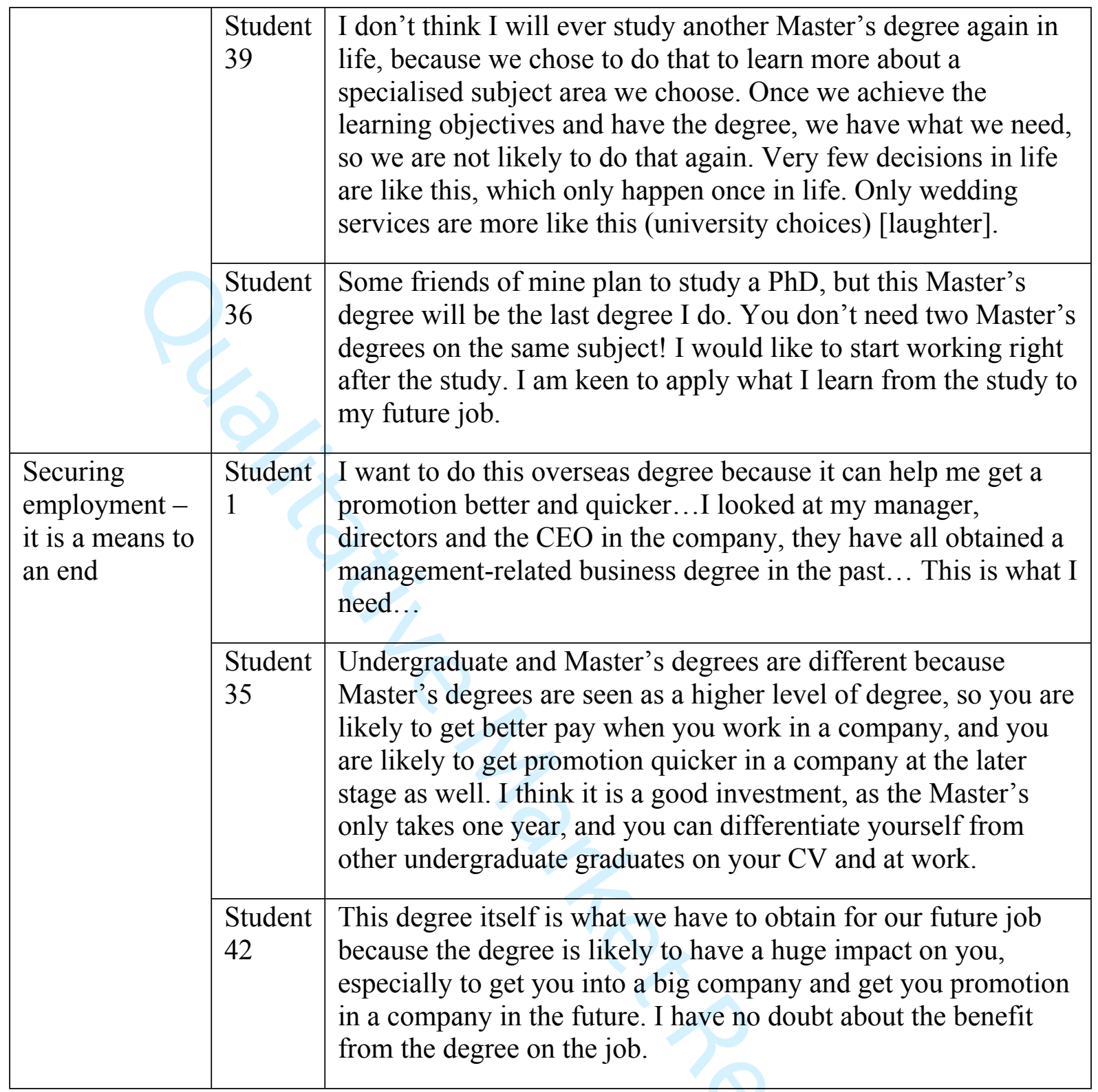

\subsection{Permanency of Purchase}

The data revealed that zero-repurchase intention affects participants' perception of university selection, as an HE degree is viewed as an enduring, non-reversible decision. For some, the pursuit of a postgraduate course of study in the UK in part represents a life-changing (experiential) activity, while for others it could have a material impact on how they are perceived by an employer (through their curricula vitae). In short, whilst a repurchase is unlikely, the impact of the purchase is likely to last a lifetime, even when the purchased service itself has reached an end. See Exhibit 3 for indicative quotations from the data. 


\begin{tabular}{|c|c|c|}
\hline \multicolumn{3}{|c|}{ Exhibit 3: Permanency of purchase } \\
\hline \multirow[t]{4}{*}{$\begin{array}{l}\text { A life- } \\
\text { changing } \\
\text { experience }\end{array}$} & $\begin{array}{l}\text { Student } \\
40\end{array}$ & $\begin{array}{l}\text { The UK study experience has made me a more dynamic person } \\
\text { because I have seen and experienced more things and met more } \\
\text { people here than in China... }\end{array}$ \\
\hline & $\begin{array}{l}\text { Student } \\
36\end{array}$ & $\begin{array}{l}\text {..the biggest learning from the study for me is to evaluate things } \\
\text { more independently and critically. Our tutors here [the UK] } \\
\text { encourage us to find information and to think critically. That is } \\
\text { very different from the expectations of our Chinese teachers. The } \\
\text { Chinese education system creates people who are good at exams, } \\
\text { but we do not have many people who can think for themselves. }\end{array}$ \\
\hline & $\begin{array}{l}\text { Student } \\
38\end{array}$ & $\begin{array}{l}\text { Majority of [Chinese] students who come and study a Master's in } \\
\text { the UK are the only child in their family, so the experiences of } \\
\text { coming to live in a foreign country are very special and precious to } \\
\text { us. Many of us are forced to become more independent, such as } \\
\text { finding accommodation and adjusting to a new lifestyle. No other } \\
\text { experiences in life are quite like this, which can transform you to } \\
\text { be someone different and not to rely on parents as much as } \\
\text { before... }\end{array}$ \\
\hline & $\begin{array}{l}\text { Student } \\
44\end{array}$ & $\begin{array}{l}\text { The experience to study and live in the UK helps me in terms of a } \\
\text { better manner to deal with people. I use phrases like "please, thank } \\
\text { you and sorry" a lot in the UK, but when I use those phrases in } \\
\text { China, no one would respond to me [laughter]. }\end{array}$ \\
\hline \multirow[t]{2}{*}{$\begin{array}{l}\text { Material } \\
\text { impact on } \\
\text { standing (as } \\
\text { per their CV) }\end{array}$} & $\begin{array}{l}\text { Student } \\
26\end{array}$ & $\begin{array}{l}\text { The name of the university where I choose to study will be shown } \\
\text { on my CV. I will become a graduate associated with the } \\
\text { university... The name of the university as well as the degree will } \\
\text { stay with me forever! }\end{array}$ \\
\hline & $\begin{array}{l}\text { Student } \\
36\end{array}$ & $\begin{array}{l}\text { The name of the university is important, because people in China } \\
\text { always want to know the ranking of your university. But I started } \\
\text { to think that it is more important what subject you study, rather } \\
\text { than just the name of the university on your CV, because the more } \\
\text { specialised your subject is, the more likely that you can contribute } \\
\text { to your future company and get promotion. }\end{array}$ \\
\hline
\end{tabular}

The finding reveals that participants were greatly affected by prestige indicators when choosing a UK university and perceived an HE purchase as having a permanent impact on their CV and broader life experience. This explains why prospective students would like to opt for universities with a better reputation (Priporas and Kamenidou, 2011), image (Wilkins and Huisman, 2015), and higher ranking based on league tables (Hazelkorn, 2007), because 
they would like to associate themselves permanently with a 'highly regarded' university degree.

\subsection{High Social Pressure}

The data revealed that the nature of an OILP is also subject to social scrutiny and pressure from close family members and relatives, as well as the general public, which further heightens the perceived risks related to choosing a UK postgraduate degree. The finding confirms the strong family influences identified in previous studies on university selection (Mazzarol and Soutar, 2002; Simoes and Soares, 2010). Indicative quotations from the data are shown in Exhibit 4.

\begin{tabular}{|l|l|l|}
\hline \multicolumn{3}{|l|}{ Exhibit 4: High social pressure } \\
\hline $\begin{array}{l}\text { Importance } \\
\text { of the general } \\
\text { public and } \\
\text { social } \\
\text { networks }\end{array}$ & $\begin{array}{l}\text { Student } \\
10\end{array}$ & $\begin{array}{l}\text { I will try to apply to study in one of the top universities.... It is } \\
\text { well known by the public and can help me advance my career } \\
\text { networks! }\end{array}$ \\
\cline { 2 - 3 } & 39 & $\begin{array}{l}\text { Student } \\
\text { The purpose of studying a Master's in the UK is very clear to } \\
\text { different and your educational level will be perceived better by } \\
\text { others. That is the biggest impact on my life and what motivates } \\
\text { me to do the study. }\end{array}$ \\
\cline { 2 - 4 } & $\begin{array}{l}\text { Student } \\
45\end{array}$ & $\begin{array}{l}\text { Society gives me pressure in terms of choosing better ranking } \\
\text { universities in which to study, as people tend to feel that if you } \\
\text { choose a bad-ranking university, it is not worth investing money } \\
\text { in the study. People in China don't know much about UK } \\
\text { universities, so they would rely on the ranking of universities... } \\
\text { People wouldn't want their kids to go to a university that they } \\
\text { have never heard of, so ranking is important... }\end{array}$ \\
\hline $\begin{array}{l}\text { Parental } \\
\text { pressure }\end{array}$ & $\begin{array}{l}\text { Student } \\
26\end{array}$ & $\begin{array}{l}\text { My parents have warned me of the importance of making sure } \\
\text { that I make the best decision... I'm anxious. }\end{array}$ \\
\cline { 2 - 4 } & $\begin{array}{l}\text { Student } \\
39\end{array}$ & $\begin{array}{l}\text { My parents did not ask me to apply to highly ranked universities, } \\
\text { but they want me to study a subject that will be useful for my } \\
\text { future job. We discussed those choices and they think this } \\
\text { subject is suitable for me. They also care if I could finish the } \\
\text { study, and complete my degree... }\end{array}$ \\
\hline $\begin{array}{l}\text { Chinese men tend to have more pressures from parents than } \\
\text { women on their study. For men, our parents would ask us to } \\
\text { think more about job prospects and the future after the study, but } \\
\text { for women, their parents might be happy as long as they get the } \\
\text { degree. The expectations are very different on both genders. It }\end{array}$ \\
\hline
\end{tabular}




\begin{tabular}{|l|l|l|}
\hline & & $\begin{array}{l}\text { also depends on the economic status of the family. If our parents } \\
\text { are not that rich, and they think it is a big investment to pay for } \\
\text { our study in the UK, they will think about the return on } \\
\text { investment and expect more from us. }\end{array}$ \\
\hline $\begin{array}{l}\text { Family } \\
\text { pressure (not } \\
\text { from parents, } \\
\text { but other } \\
\text { family } \\
\text { members) }\end{array}$ & $\begin{array}{l}\text { Student } \\
36\end{array}$ & $\begin{array}{l}\text { My grandad encouraged me to come and study in the UK, } \\
\text { because he dreamed to study abroad when he was young, but he } \\
\text { wasn't able to do that due to economic factors. We can afford } \\
\text { that now, so he wanted me to come and expand life experiences } \\
\text { through the study. }\end{array}$ \\
\cline { 2 - 3 } & $\begin{array}{l}\text { Student } \\
36\end{array}$ & $\begin{array}{l}\text { My parents have never studied abroad, so they didn't comment } \\
\text { much... However, my uncle, who works in a big company, } \\
\text { suggested that I choose better ranked universities, and if I cannot } \\
\text { do that, I should at least choose a more specialised subject to } \\
\text { study. So I followed his advice... }\end{array}$ \\
\cline { 2 - 3 } & $\begin{array}{l}\text { Student } \\
41\end{array}$ & $\begin{array}{l}\text { My dad asked me to decide if I want to work for the government } \\
\text { or to study a Master's in the UK, and I decided to come and do } \\
\text { the Master's. But my aunties were against my idea, as they think } \\
\text { that for a woman of my age, I should think about marriage and } \\
\text { try to get a stable job... }\end{array}$ \\
\hline
\end{tabular}

The finding reveals various sources of social pressure on students' HE choice, echoing previous studies that found that interpersonal sources of information can greatly affect students' decision making (Mazzarol and Soutar, 2002; Simoes and Soares, 2010; Wilkins and Huisman, 2015) and the importance of perceived social values when comparing alternatives (Sheth et al., 1991). The permanency of an OILP explains why consumers receive extremely high social pressure to ensure the 'best decision' is made, based in this case on university ranking and personal career prospects. However, high social pressure may cause consumers to become more anxious, leading to engagement in an extensive information search.

\subsection{Extensive Information Search}

The participants engaged in extensive information searches due to zero-repurchase intention and permanency of purchase, which heightened the complexity as well as the length of the decision-making process. For instance, the information gathered from different sources was sometimes duplicated. Various information sources were also employed to ensure the best decision was reached through several stages of screening (Lye et al., 2005). Exhibit 5 reproduces indicative quotations from the data. 


\begin{tabular}{|c|c|c|}
\hline \multicolumn{3}{|c|}{ Exhibit 5: Extensive information search } \\
\hline \multirow[t]{3}{*}{$\begin{array}{l}\text { A variety of } \\
\text { information } \\
\text { sources are } \\
\text { consulted as } \\
\text { multiple } \\
\text { screening }\end{array}$} & $\begin{array}{l}\text { Student } \\
24\end{array}$ & $\begin{array}{l}\text { I kind of decided to go to university X for its Y degree. I can see } \\
\text { the obvious good scores from the league tables, but I still prefer } \\
\text { checking it out by talking to people who have studied in the UK } \\
\text { before. I'm always happier if I've heard good things about this } \\
\text { university. It makes me feel more assured about my decision. }\end{array}$ \\
\hline & $\begin{array}{l}\text { Student } \\
37\end{array}$ & $\begin{array}{l}\text { I also googled the names of universities and check online forums } \\
\text { posted by students to check past students' comments on the } \\
\text { universities where they had studied. They are also important for } \\
\text { me, as they show how happy past students were about their } \\
\text { courses. }\end{array}$ \\
\hline & $\begin{array}{l}\text { Student } \\
45\end{array}$ & $\begin{array}{l}\text { When I knew nothing about the UK universities, my agent was } \\
\text { very important as my information source...I also used online } \\
\text { reviews to ask about if S University is good. I added the QQ } \\
\text { community of Chinese students from my interested universities, } \\
\text { because I think the opinions from current students and alumni } \\
\text { will be the most honest and trustworthy on if the course is good. }\end{array}$ \\
\hline \multirow[t]{2}{*}{$\begin{array}{l}\text { Verifying } \\
\text { experts' } \\
\text { advice entails } \\
\text { pressure }\end{array}$} & $\begin{array}{l}\text { Student } \\
27\end{array}$ & $\begin{array}{l}\text { I have already gathered a lot of information about University X. } \\
\text { This was recommended by the student recruitment agent that I } \\
\text { used. I know it is a good university anyway, as I heard good } \\
\text { things about it. Just to make sure, I've also checked its ranking on } \\
\text { the league tables and went onto its Taiwanese alumni group on } \\
\text { Facebook to seek a second opinion... }\end{array}$ \\
\hline & $\begin{array}{l}\text { Student } \\
35\end{array}$ & $\begin{array}{l}\text { Apart from agents, I also used league tables, such as the Guardian } \\
\text { ranking. I checked the overall university ranking and then the } \\
\text { subject ranking to decide what to apply... }\end{array}$ \\
\hline \multirow[t]{3}{*}{$\begin{array}{l}\text { Scale of } \\
\text { information } \\
\text { takes time to } \\
\text { digest and } \\
\text { process }\end{array}$} & $\begin{array}{l}\text { Student } \\
1\end{array}$ & $\begin{array}{l}\text { There is too much information! I know so little about the whole } \\
\text { thing of studying abroad... it is going to take me a long time to } \\
\text { go through all these before I can make a real choice in terms of } \\
\text { where, which university, which course to go for... }\end{array}$ \\
\hline & $\begin{array}{l}\text { Student } \\
36\end{array}$ & $\begin{array}{l}\text { Unlike other things I purchased before, it took } 6 \text { months for me to } \\
\text { collect information, apply to universities, wait for offers, and } \\
\text { decide which one to select. No other purchases are like this, } \\
\text { because you cannot go wherever you like, you need to wait for } \\
\text { their offers and need to have the grades they ask for. }\end{array}$ \\
\hline & $\begin{array}{l}\text { Student } \\
43\end{array}$ & $\begin{array}{l}\text { It was a difficult decision to make after receiving offers from } \\
\text { universities when I need to choose one to enrol. Compared with } \\
\text { other decisions that I have to make in life, this is a truly difficult } \\
\text { choice... a lot of information to understand and to } \\
\text { compare... once, twice, three times... }\end{array}$ \\
\hline
\end{tabular}


As prospective students are pressurised by the amount of information during the lengthy HE decision-making process (Moogan and Baron, 2003), they rely on different information sources, such as family, teachers, and university prospectuses, to evaluate alternatives, echoing previous findings by Wilkins and Huisman (2015). Our paper disclosed that word-ofmouth (WOM) reports from family and friends, as well as online word-of-mouth via online discussion forums from alumni and current students, are heavily consulted in the final stage of OILP decision making. Hence, it is crucial for UK universities to provide consistently high-quality educational experiences, in order to facilitate WOM recommendations from current students and alumni to prospective students. In other words, current and past students of UK universities should not be seen as 'one-off' customers who only consumed the OILP service provided by a UK HE institution once, but as customers who can bring 'lifetime value' (Haenlein et al., 2007) to the university from which they graduate.

Considering how unfamiliar prospective consumers are with the UK HE that they are about to purchase, OILP institutions are advised to employ a variety of sources to provide information, as well as reassure consumers, to help simplify their HE decision making and reduce the stress involved in the process (Yen et al., 2012).

\section{Discussion}

This study marks the key differences between OILPs and infrequent purchases. Due to zerorepurchase intention and permanency of purchase, consumers of OILPs showed a greater extent than consumers of infrequent purchases on behaviour criteria, such as decision-making time, decision waves, perceived risk, involvement, and need for assurance, leading to a widespread information search from various sources over an extensive period of time. Table $\underline{3 \text { compares the differences and similarities between infrequent and once-in-a-lifetime }}$ purchases.

\section{[INSERT TABLE 3 HERE]}

Firstly, it shows that, regardless of how a purchase is perceived as a means to an end, a special experience to be cherished, or a combination of the two, consumers fully acknowledge that they have no intention of repeating the purchase in the future. This challenges an existing assumption, wherein marketers could attempt to increase consumers' repurchase intention by working on building trust, increasing satisfaction and offering 
products/services regarded as being of high quality (Fang et al., 2014; Saleem et al., 2017). For OILP decisions, consumer loyalty may be revisited. Although our participants may not intend to repeat their UK degree, this does not mean that their experience is not valued, since they are highly likely to make positive WOM recommendations to prospective consumers if their own university experience was a good one.

Secondly, whilst a repurchase will not be performed, the permanent nature of such a purchase will have an everlasting impact on their lives. Consumers understand that once the decision is made, the consequence of that decision will stay with them for many years, even when the consumption of the once-in-a-lifetime service has come to an end. The permanency of the purchase has not really been discussed in depth in previous studies, while the closest examples of a consumption that has a long-lasting impact on consumers' lives are purchases such as wedding dresses (Boden, 2001), wedding services (Lau and Hui, 2010) and honeymoon destination choices (Lee et al., 2010).

Thirdly, consumers endure high levels of social pressure during their decision making because their decisions are not only judged by themselves, but are also under social scrutiny from those with whom they associate and aspire to emulate. Previous literature has evaluated relevant concepts such as the relationship between perceived risk and purchases (Chiu et al., 2014), perceived risk and purchase frequency (Martin et al., 2015), parental influence on Generation Y's purchases (Wiese and Kruger, 2016) and parental influence on ethical consumption (Gentina et al., 2016). However, an OILP is different from these purchases, due to the high levels of social pressure that participants receive when deciding the most suitable university and course to study and trying to fulfil family expectations with regard to university choice.

Fourthly, in order to ensure that the best decision is made, consumers undertake wide-ranging and complex information searches over an extensive period of time that involve several waves of screening (Lye et al., 2005), by looking for various types of information from different sources, such as eWOM from current students and alumni on the performance of HE institutions.- - Although HE institutions cannot control eWOM from current students and alumni, the literaturefindingit (Stephenson and Yerger, 2014) indicates that HE institutions need to engage their current students when they are still enrolled atwith the university, in order to cultivate the relationship further them-when they become alumni. 3 
eompares the differences and similarities been infrequent and once-in lifetime purases.

\section{HESERT TABLE 3 HERE}

Finally, by using HE as a classic example of an OILP, this study not only sheds new light on understanding an OILP as a purchase decision, but also advances our comprehension of the phenomenon of HE selection by revealing how zero-repurchase intention leads to permanency of purchase in university selection, and how both zero-repurchase intention and permanency of purchase lead to high social pressure and extensive information search. By theoretically explaining the notion of an OILP and empirically exploring the HE characteristics of OILPs, this study represents the first attempt to discuss how zerorepurchase intention determines and explains consumers' decision making when choosing an HE degree.

\section{Implications}

This study found that OILPs are significantly different from infrequent purchases as the buying process differs substantially. Specifically, OILPs differ from infrequent purchases in terms of their zero-repurchase intention, long-lasting impact and level of social scrutiny. As a result, the OILP decision-making process is lengthy because consumers need time to understand and compare information from different sources to ensure, as well as to reassure themselves, that the best decision is made. This study sheds new light on studies of consumer purchase decisions by differentiating OILPs from infrequent purchases and explicitly explaining OILP characteristics, thus opening a new research avenue for future studies.

This study also expands previous understanding of HE marketing and, in particular, international students' decision-making processes. By highlighting and explaining the nature of an OILP when choosing an overseas degree, this paper brings a new theoretical dimension by studying the complex decision-making process in university selection (Bonnema and Van der Waldt, 2008; Hemsley-Brown and Oplatka, 2015; Maringe, 2006).

\section{Managerial Advice}

The findings of this research are of value to HE institutions. Whilst the findings suggest that OILPs are typically associated with high social pressure and a permanent impact, and 
consumers undertake extensive information searches and screening before making their final decision, HE institutions are encouraged to provide fact-based information from their own marketer-controlled sources, as well as to work on generating positive electronic word-ofmouth(e WOM) on their own websites and social media. For example, HE institutions could facilitate eWOM about the university via Facebook and LinkedIn.

HE marketing managers should be cognisant of the range of information collected by prospective OILP customers from a variety of different sources. OILP customers perceive non-marketing information as more reliable than marketing promotional materials and as better able to assist them during their decision making. However, whilst fact-based information helps consumers compare alternatives, WOM from close family and friends often provides the psychological reassurance that consumers seek when making an OILP. Thirdparty referrals, such as published league tables and reviews (Hazelkorn, 2007), as well as eWOM via online discussion forums from alumni (Yang and Mutum, 2015), can also be employed by consumers as criteria to help support their decisions by reducing their anxiety.

As the impact of an OILP is ever-lasting, HE institutions could usefully nurture established customer relationships, even after the purchase has been made and the consumption experience has reached an end. Whilst the notion of an OILP suggests that these customers do not have any intention of repeating the purchase, this does not suggest a lack of brand loyalty (Fournier and Yao, 1997). Instead, due to the permanent effect of an OILP, satisfied customers are more likely to become very loyal and take on the role of self-nominated brand ambassadors to spread positive WOM to future customers (Mazzarol et al., 2007; McAlexander et al., 2004). HE institutions should invest in building long-term customer relationships with alumni in the post-purchase stage, as active alumni can become online influencers via social media, sharing graduate testimonials and endorsing their previous $\mathrm{HE}$ institutions. Positive online WOM from alumni is extremely influential with regard to the final purchase choices of potential consumers (Yang and Mutum, 2015).

See-To and Ho (2014) examine how the interaction between consumers' trust, value cocreation and eWOM affect purchase intention on social networking sites. They report that eWOM has a direct impact on purchase intention, showing that both trust and the source of the message moderate the impact of eWOM on purchase intention. HE institutions should, therefore, aim to create an alumni community following the graduation ceremony, as the 
sense of community will increase the likelihood of consumers spreading positive eWOM of a brand. For example, Kohler et al. (2011) propose the term 'co-creation evangelism' to describe the behaviour of "brand zealots" - consumers who are active and committed to spreading positive eWOM and trying fervently to convince or persuade others to become engaged in the brand. Therefore, HE institutions are recommended to set up alumni networks overseas as well as online and host annual celebration events all over the world to stay connected with their graduates, as the latter will not only support their brands by action (e.g. donations to various events), but also by their influence on prospective students.

We advise HE institutions to work closely with alumni associations, aiming at forming longterm relationships to increase their participation in activities as well as brand loyalty to the university. As the Internet is a cost-effective marketing tool, we suggest HE institutions design their websites to better sustain relationships with alumni. Many HE institutions merely encourage alumni to keep in touch, rather than initiating contact with them. We suggest HE institutions to contact alumni proactively after graduation and update them continually using emails and university websites with the aim of involving alumni as partners of the university.

HE institutions might have limited resources, so we recommend them to prioritise building relationships with satisfied and academically sound alumni rather than all alumni, aiming at strengthening relational bonds with them by informing them of new university initiatives, engaging them in social activities and sharing feedback on course improvement. Active alumni can be converted into university brand ambassadors who verbally support and praise the university to others in social settings, or encourage friends to attend the university, both directly in face-to-face encounters and online. HE institutions can also invite active alumni to speak to prospective students at open days or recruitment events.

In addition, HE institutions could cross-sell other services to alumni, such as online life-long learning courses or career enhancement webinar sessions. Those events are extra incomegeneration opportunities for HE institutions, while alumni would also benefit in their professional development and by networking with other alumni.

Aaker (1991) defines brand identity as the sum of brand meanings expressed as a product, organisation, symbol and person. Marketers of HE institutions intend to position the 
university brand in stakeholders' minds to create a brand identity (Anisimova, 2014).

However, leaders of HE institutions are not the sole creator of brand identity. Based on the findings of this study, leaders of HE institutions are advised to involve current students, who are one key type of stakeholders, inte co-creatinge HE experiences from the point of enrolment, so students will no longer see themselves as "consumers of HE services", but could regardsee themselves more as "partners" of their chosen university. If current students and alumni can be encouraged by their university to become more active actors, who interact better with their lecturers as well as supporting employees of HE institutions, they can cocreate more meaningful HE experiences for themselves. As a result, satisfied current students and alumni could contribute further to the marketing of HE institutions andthat draw more potential students into the university courses via positive eWOM.

\section{Limitations and Future Research Directions}

\section{Whils this empirieal study of an OHLP is signifieant in confirming the existene of the phenemenon and showing that it differs from an infrequent purchase, the insights frem this sty analytically generalisable buto notaim bestatically generalisable-In this study, the participants' cultural background is either Taiwanese or Chinese. It is possible for Chinese and Taiwanese participants of this study to perceive OILPs in HE differently, in comparison withte participants from other cultural backgrounds. Chinese and Taiwanese participants might be deeply affected by Confucianism and value education highly. However, in this study, we focus on the purchase of an overseas postgraduate degree course as a typical example of an OILP. It is important to start with an exploratory research, in order to identify and define the concept of anthe OILP in an HE context. We acknowledge the limitation of the selected samples due to the cultural background of the participants, while-we also appreciatinge that the carefully selected cultural background of the participants provides insight into the understanding of OILPs.}

Whilst this empirical study of an OILP is significant in confirming the existence of the phenomenon and showing that it differs from an infrequent purchase, the insights from this study are analytically generalisable but do not claim to be statistically generalisable. Future research is recommended to further validate the notion of an $\mathrm{OILP}_{2}$ using quantitative data collected from different OILP products/services in various markets. 
Additionally, whilst the concept of an OILP defines a zero-repurchase decision, it is important for future research to revisit the concept of consumer loyalty in relation to OILPs. For example, a loyal OILP consumer may be more likely to engage in positive WOM recommendations and testimonials than consumers making infrequent purchases due to the permanency of an OILP and the associated social esteem.

\title{
References
}

\section{Aaker, D. A. „(1991), “Managing Brand Equity: Capitalizing on the Value of a Brand Name.”.} London: The Free Press.

\begin{abstract}
Ahmad, S. Z.; and Buchanan, F. R. (2015), "Motivation factors in students' decision to study at international branch campuses in Malaysia”, Studies in Higher Education, pp. 1-18.

Andreassen, T._W. and Lindestad, B. (1998), "Customer loyalty and complex services: The impact of corporate image on quality, customer satisfaction and loyalty for customers with varying degrees of service expertise”, International Journal of Service Industry Management, Vol. 9 No._1, pp. 7-23.
\end{abstract}

Anisimova, T. (2014), "Benchmarking desired corporate brand image in relation to stakeholders: a managerial perspective", Qualitative Market Research: An International Journal, Vol. 17 No. 4, pp. 441-463.

Armstrong, J. and Lumsden, B. (1999), “Impact of universities' promotional materials on college choice", Journal of Marketing for Higher Education, Vol. 9 No. 2, pp. 83-91.

Babu, M. S. H., and Shams, S. (2015), 'Factors influencing consumers' choice of ice-cream: a study on impulse buying behaviour", Journal of Marketing, Vol. 16 No. 1, pp. 225242.Binsardi, A. and Ekwulugo, F. (2003), "International marketing of British education: Research on the students' perception and the UK market penetration”, Marketing Intelligence \& Planning, Vol. 1 No. 5, pp. 318-327. 
Boden, S. (2001), “'Superbrides': wedding consumer culture and the construction of bridal identity". Sociological Research Online, Vol. 6 No. 1, pp. 1-14.

Bonnema, J. and Van der Waldt, D. L.R. (2008), "Information and source preferences of a student market in higher education", International Journal of Educational Management, Vol. 22 No. 4, pp. 314-327.

British Council, (2008), “International student mobility in East Asia: executive summary”, available at: http://www.eahep.org/web/images/Malaysia/bc\%20\%20asia\%20student \%20mobility\%20-\%20summary.pdf [accessed 27 June 2012]

Broecke, S. (2015), “University rankings: do they matter in the UK?", Education Economics, Vol. 23 No. 2, pp. 137-161.Bui, M., Krishen, A. S., and Bates, K. (2011), "Modeling regret effects on consumer post-purchase decisions", European Journal of Marketing, Vol. 45 No. 7/8, pp. 1068-1090.

Bunce, L., Baird, A., and Jones, S. E. (2017), “The student-as-consumer approach in higher education and its effects on academic performance", Studies in Higher Education, Vol. 42 No. 11, pp. 1958-1978.

Bunn, M. D. (1993), “Taxonomy of buying decision approaches”. Journal of Marketing, Vol. 57 No. 1, pp. 38-56.

Burgess, R. G. (1982), “The unstructured interview as a conversation”. Field research: A sourcebook and field manual, pp. 107-111. George Allen \& Unwin, London.

Chapman, D. W. (1981). "A model of student college choice”, The Journal of Higher Education, Vol. 54 No. 5, pp. 490-505.

Charmaz, K. (1983), "Loss of self: a fundamental form of suffering in the chronically ill”, Sociology of Health \& Illness, Vol. 5 No. 2, pp. 168-195.

China Post, (2008), "University admission rate hits record high of over 100\%”, available at: http://www.chinapost.com.tw/taiwan/national/national\%20news/2008/07/29/167582/U niversity-admission.htm [Accessed 5 July 2012] 
China Post, (2009), “Good English ability helps people gain jobs, higher pay: survey”, available at: http://www.chinapost.com.tw/business/2009/10/20/229303/GoodEnglish.htm [Access 22 August 2012]

Chiu, C. M., Wang, E. T., Fang, Y. H., and Huang, H. Y. (2014), 'Understanding customers' repeat purchase intentions in $\mathrm{B} 2 \mathrm{C}$ e-commerce: the roles of utilitarian value, hedonic value and perceived risk". Information Systems Journal, Vol. 24 No. 1, pp. 85-114.

Clark, N., (2010), “Education in Taiwan”. available at: https://wenr.wes.org/2010/05/wenrmay-2010-feature [accessed 12 April 2018]

Clarke, G. and Brown, M.A. (1998), "Consumer attitudes to the higher education application process", Journal of Marketing for Higher Education, Vol. 8 No. 4, pp. 83-96.

Connor, H., Burton, R., Pearson, R., Pollard, E. and Regan, J. (1999), "Making the Right Choice: How Students Choose Universities and Colleges: the Survey of Applicants." London: The Institute for Employment Studies.

Connor, H. and Dewson, S. (2001), "Social Class and Higher Education: Issues Affecting Decisions on Participation by Lower Social Class Groups”, [pdf] London: Department for Education and Skills, Available at: $<\underline{\text { http://dera.ioe.ac.uk/4621/1/RR267.pdf }>}$ [Accessed 20 August 2014].Conway, T., Mackay, S., and Yorke, D. (1994). "Strategic planning in higher education: Who are the customers", International Journal of Educational Management, Vol. 8 No. 6, pp. 29-36.

Cubillo, J.M., Sanchez, J. and Cervino, J. (2006). “International students' decision-making process", International Journal of Educational Management, Vol. 20 No. 2, pp. 101115.

Daily, C. M., Farewell, S. and Kumar, G. (2010), "Factors influencing the university selection of international students", Academy of Educational Leadership Journal, Vol. 14 No. 3, pp. 59-75.

Dellarocas, C., and Narayan, R. (2006), “A statistical measure of a population's propensity to engage in post-purchase online word-of-mouth", Statistical Science, Vol. 21 No. 2, pp. 277-285. Douglas, J. A., Douglas, A., McClelland, R. J., and Davies, J. (2015), 
"Understanding student satisfaction and dissatisfaction: an interpretive study in the UK higher education context", Studies in Higher Education, Vol. 40 No. 2, pp. 329-349 Duarte, P., e Silva, S. C., \& Ferreira, M. B. (2018), "How convenient is it? Delivering online shopping convenience to enhance customer satisfaction and encourage eWOM", Journal of Retailing and Consumer Services, Vol. 44, pp. 161-169.

Fang, Y., Qureshi, I., Sun, H., McCole, P., Ramsey, E., and Lim, K. H. (2014), “Trust, Satisfaction, and Online Repurchase Intention: The Moderating Role of Perceived Effectiveness of E-Commerce Institutional Mechanisms”. MIS Quarterly, Vol. 38 No. 2, pp. 407-427.

Fournier, S. and Yao, J. (1997), "Reviving brand loyalty: A reconceptualization within the framework of consumer-brand relationships", International Journal of Research in Marketing, Vol. 14 No. 5, pp. 451-472.

Franklin, M. (1995), “The effects of differential college environments on academic learning and student perceptions of cognitive development", Research in Higher Education, Vol. 36, pp. 127-153.

Gentina, E., Shrum, L. J., Lowrey, T. M., Vitell, S. J., and Rose, G. M. (2016), “An integrative model of the influence of parental and peer support on consumer ethical beliefs: The mediating role of self-esteem, power, and materialism”. Journal of Business Ethics, pp. 1-14.

Gibbons, S., Neumayer, E., and Perkins, R. (2015), "Student satisfaction, league tables and university applications: evidence from Britain", Economics of Education Review, Vol. 48, pp. 148-164.

Grundey, D. (2008), “Experiential Marketing vs. Traditional Marketing: creating rational and emotional liaisons with consumers". The Romanian Economic Journal, Vol. 29 No. 3, pp. 133-151. Haenlein, M., Kaplan, A. M., and Beeser, A. J. (2007), “A model to determine customer lifetime value in a retail banking context". European Management Journal, Vol. 25 No 3, pp. 221-234.Harker, D., Slade, P. and Harker, M. (2001), "Exploring the decision process of "School Leavers" and "Mature Students" in 
Hazelkorn, E. (2007), "Impact and influence of league tables and ranking systems on higher education decision-making", Higher Education Management Policy, Vol. 19 No. 2, pp. 87-110.

Hemsley-Brown, J. and Oplatka, I. (2006), "Universities in a competitive global marketplace: A systematic review of the literature on higher education marketing", International Journal of Public Sector Management, Vol. 19 No. 4, pp. 316-338.

Hemsley-Brown, J., and Oplatka, I. (2015), “University choice: what do we know, what don't we know and what do we still need to find out?" International Journal of Educational Management, Vol. 29 No. 3, pp. 254-274.

Hill, F. M. (1995), "Managing service quality in higher education: The role of the student as primary consumer", Quality Assurance in Education, Vol. 3 No. 3, pp. 10-21.

Hossler, D., Schmit, J. and Vesper, N. (1999), “Going to College: How Social, Economic, and Educational Factors Influence the Decisions Students Make”, Baltimore: The Johns Hopkins University Press.

Jones, M. A.-; and Taylor, V. A. (2018), "Marketer requests for positive post-purchase satisfaction evaluations: Consumer depth interview findings", Journal of Retailing and Consumer Services, Vol. 41, pp. 218-226.

Joseph, M., and Joseph, B. (1997), "Service quality in education: a student perspective", Quality Assurance in Education, Vol. 5 No. 1, pp. 15-21.

Karimi, S., Papamichail, K. N., and Holland, C. P. (2015), “The effect of prior knowledge and decision-making style on the online purchase decision-making process: A typology of consumer shopping behaviour". Decision Support Systems, Vol. 77, pp. 137-147. 
King, N., (2004), "Using templates in the thematic analysis of text", in Cassell, C. and Symon, G. (Ed.). Essential guide to qualitative methods in organizational research, Sage, London, pp. 256-271.

Kohler, T., Fueller, J., Stieger, D. and Matzler, K. (2011), 'Avatar-based innovation: Consequences of the virtual co-creation experience', Computers in Human Behavior, Vol. 27, No. 1, pp. 160-168.

Kotler, P. and Fox, K., (1985), “Strategic Marketing for Educational Institutions”, Englewood Cliffs: Prentice-Hall.

Kumar, A., Vohra, A., and Dangi, H. K. (2017), "Consumer decision-making styles and post purchase behaviour of poor for Fast Moving Consumer Goods", International Journal of Consumer Studies, Vol. 41 No. 2, pp. 121-137. Kuo, Y. F., Wu, C. M., and Deng, W. J. (2009), "The relationships among service quality, perceived value, customer satisfaction, and post-purchase intention in mobile value-added services", Computers in Human Behavior, Vol. 25 No. 4, pp. 887-896.

Lau, C. K., and Hui, S. H. (2010), "Selection attributes of wedding banquet venues: An exploratory study of Hong Kong prospective wedding couples”. International Journal of Hospitality Management, Vol. 29 No. 2, pp. 268-276.

Lee, C., Huang, H and Chen, W., (2010), “The Determinants of Honeymoon Destination Choice-The Case of Taiwan", Journal of Travel \& Tourism Marketing, Vol. 27 No. 7, pp. 676-693.

Lee, N. and Greenley, G. (2008), "The primacy of theory. European Journal of Marketing”, Vol. 42 No. 9/10, pp. 873-878.

Lye, A., Shao, W., Rundle-Thiele, S. and Fausnaugh, C. (2005), "Decision waves: consumer decisions in today's complex world”, European Journal of Marketing, Vol. 39 No. 1/2, pp. $216-230$.

Maringe, F. (2006), "University and course choice: Implications for positioning, recruitment and marketing", International Journal of Educational Management, Vol. 20 No. 6, pp. 466-479. 
Maringe, F., and Carter, S. (2007), "International students' motivations for studying in UK HE: Insights into the choice and decision making of African students", International Journal of Educational Management, Vol. 21 No. 6, pp. 459-475.

Martin, J., Mortimer, G., and Andrews, L. (2015), "Re-examining online customer experience to include purchase frequency and perceived risk". Journal of Retailing and Consumer Services, Vol. 25, pp. 81-95.

Mazzarol, T. and Soutar, G. N. (2002), "Push-Pull factors influencing international student destination choice", The International Journal of Educational Management, Vol.16 No. 2, pp. 82-90.

Mazzarol, T., Sweeney, J. C. and Soutar, G. N. (2007), “Conceptualizing word-of-mouth activity, triggers and conditions: an exploratory study", European Journal of Marketing, Vol. 41 No. 11/12, pp. 1475 - 1494.

McAlexander, J. H., Koenig, H. F., and Schouten, J. W. (2004), "Building a university brand community: The long-term impact of shared experiences", Journal of Marketing for Higher Education, Vol. 14 No. 2, pp. 61-79.

Mitchell, V. (1992), “Understanding consumers' behaviour: can perceived risk theory help?”, Management Decision, Vol. 30 No. 3, pp. 26-31.

Mohan, G., Sivakumaran, B., and Sharma, P. (2013), "Impact of store environment on impulse buying behaviour", European Journal of Marketing, Vol. 47 No. 10, pp. 17111732.Moogan, Y. J. and Baron, S. (2003), “An analysis of student characteristics within the student decision making process", Journal of Further and Higher Education, Vol. 27 No. 3, pp. 271-287. Morse, J. M. (2000), “Determining sample size”, Qualitative Health Research, Vol. 10 No. 1, pp. 3-5.

Nixon, E., Scullion, R., and Hearn, R. (2016), "Her majesty the student: marketised higher education and the narcissistic (dis) satisfactions of the student-consumer", Studies in Higher Education, pp. 1-21. 
Nwankwo, S., Hamelin, N., and Khaled, M. (2014), "Consumer values, motivation and purchase intention for luxury goods", Journal of Retailing and Consumer Services, Vol. 21 No. 5, pp. 735-744.

Patterson, P., Romm, T. and Hill, C., (1998), “Consumer satisfaction as a process: a qualitative retrospective longitudinal study of overseas students in Australia", Journal of Professional Services Marketing, Vol. 16 No.1, pp. 135-157.

Peterson, R. A., Balasubramanian, S. and Bronnenberg, B. J. (1997), "Exploring the implications of the internet for consumer marketing", Journal of the Academy of Marketing Science, Vol. 25 No. 4, pp. 329-346.

Phau, I. and Poon, S.M. (2000), "Factors influencing the types of products and services purchased over the internet", Internet Research, Vol. 10 No.2, pp. 102-113.

Pimpa, N. (2004), “The relationship between Thai students' choices of international education and their families", International Education Journal, Vol. 5 No. 3, pp. 352-359.

Priporas, C., and Kamenidou, I. (2011), "Perceptions of potential postgraduate greek business students towards UK universities, brand and brand reputation", Journal of Brand Management, Vol. 18 No.4, pp. 264-273.

Pucciarelli, F., and Kaplan, A. (2016), "Competition and strategy in higher education: Managing complexity and uncertainty”, Business Horizons, Vol. 59 No. 3, pp. 311-320.

Redwood, F. (2000), “Do you really want to go to university?", Sunday Times, 30 January, pp. 25.

Saleem, M. A., Zahra, S., and Yaseen, A. (2017). Impact of service quality and trust on repurchase intentions-the case of Pakistan airline industry. Asia Pacific Journal of Marketing and Logistics, 29(5), 1136-1159.

Santos, J., and Boote, J. (2003), "A theoretical exploration and model of consumer expectations, post-purchase affective states and affective behaviour", Journal of Consumer Behaviour: An International Research Review, Vol. 3 No. 2, pp. 142-156. 
See-To, E. W. and Ho, K. K. (2014), "Value co-creation and purchase intention in social network sites: The role of electronic word-of-mouth and trust-A theoretical analysis", Computers in Human Behavior, Vol. 31, pp. 182-189.

Silverman, D. (2006), “Interpreting qualitative data: Methods for analyzing talk, text and interaction", Sage, London.

Simoes, C., and Soares, A. M. (2010), “Applying to higher education: Information sources and choice factors", Studies in Higher Education, Vol. 35 No.4, pp. 371-389.

Sheth, J. N., Newman, B. I., and Gross, B. L. (1991), "Why we buy what we buy: A theory of consumption values", Journal of Business Research, Vol. 22 No.2, pp. 159-170.

Shiv, B., and Fedorikhin, A. (1999), "Heart and mind in conflict: The interplay of affect and cognition in consumer decision making", Journal of Consumer Research, Vol. 26 No. 3, pp. 278-292.

Soo, K. T. and Elliott, C. (2010), "Does price matter? Overseas students in UK higher education", Economics of Education Review, Vol. 29 No. 4, pp. 553-565.

Soutar, G.N. and Turner, J.P. (2002), “Students' preferences for university: A conjoint analysis", The International Journal of Educational Management, Vol. 16 No. 1, pp. $40-45$.

Souto-Otero, M., and Enders, J. (2017), “International students' and employers' use of rankings: a cross-national analysis", Studies in Higher Education, Vol. 42 No. 4, pp. 783-810.Strauss, A. L. (1987), “Qualitative analysis for social scientists”, Cambridge University Press, Cambridge.

Stephenson, A., and B. Yerger, D. (2014), “Optimizing engagement: brand identification and alumni donation behaviors". International Journal of Educational Management, Vol. 28 No. 6, pp. 765-778.

Vahidov, R. and Ji, F. (2005), “A diversity-based method for infrequent purchase decision support in e-commerce", Electronic Commerce Research and Applications, Vol. 4 No. 2, pp. 143-158. 
Veloutsou, C., Paton, R.A. and Lewis, J., (2005), "Consultation and reliability of information sources pertaining to university selection: Some questions answered?", International Journal of Educational Management, Vol. 19 No.4, pp. 279-291.

Vigneron, F. and Johnson, L. W. (1999), “A review and a conceptual framework of prestigeseeking consumer behavior”, Academy of Marketing Science Review, Vol. 1 No. 1, pp. $1-15$.

Vrontis, D., Thrassou, A. and Melanthiou, Y. (2007), “A contemporary higher education student-choice model for developed countries", Journal of Business Research, Vol. 60 No. 9, pp. 979-989.

Wiese, M., and Kruger, L. (2016), "Parental influence on consumer and purchase behaviour of Generation Y”, Journal of Consumer Sciences, Vol. 44, pp. 21-31.

Wilkins, S., and Huisman, J. (2015), "Factors affecting university image formation among prospective higher education students: The case of international branch campuses", Studies in Higher Education, Vol. 40 No.7, pp. 1256-1272.

Woodall, T., Hiller, A., and Resnick, S. (2014), "Making sense of higher education: Students as consumers and the value of the university experience", Studies in Higher Education, Vol. 39 No. 1, pp. 48-67.

Yang, H. P., and Mutum, D. S. (2015), "Electronic word-of-mouth for university selection", Journal of General Management, Vol. 40 No.4, pp. 23-44.

Yen, D. A., Yang, H. P. and Cappellini, B. (2012), "Ranking gives power: Relationships between UK universities and Chinese agents", Journal of General Management, Vol. 38 No. 1, pp. 23-44.

Yost, M., Jr. and Tucker, S.L. (1995”, “Tangible evidence in marketing a service: the value of a campus visit in choosing a college". Journal of Marketing for Higher Education, Vol. 6 No. 1, pp. 47-67. 
Table 1: Characteristics of infrequent purchases

\begin{tabular}{|c|c|c|}
\hline Authors & Characteristics & Typical examples \\
\hline Mitchell, 1992 & $\begin{array}{l}\text { - Complex consumer decision making } \\
\text { - High involvement } \\
\text { - Expensive purchases } \\
\text { - High perceived risks }\end{array}$ & $\begin{array}{ll}\text { - } & \text { Life } \\
\text { insurance } \\
\text { - } \\
\text { TV repair } \\
\text { services }\end{array}$ \\
\hline $\begin{array}{l}\text { Peterson et al., } \\
1997\end{array}$ & $\begin{array}{l}\text { - High cost and infrequently purchased } \\
\text { - Intangible value proposition } \\
\text { - High differentiation potential }\end{array}$ & $\begin{array}{ll}\text { - } & \text { Legal } \\
\text { services } \\
\text { - } & \text { Stereo }\end{array}$ \\
\hline $\begin{array}{l}\text { Andreassen and } \\
\text { Lindestad, } 1998\end{array}$ & $\begin{array}{l}\text { - High monetary cost } \\
\text { - Infrequent consumption } \\
\text { - Quality attributes of the services are } \\
\text { difficult to evaluate }\end{array}$ & $\begin{array}{l}\text { systems } \\
\text { - Cars } \\
\text { - Software } \\
\text { purchases }\end{array}$ \\
\hline $\begin{array}{l}\text { Vigneron and } \\
\text { Johnson, } 1999\end{array}$ & $\begin{array}{l}\text { - Extreme high-involvement decision } \\
\text { making } \\
\text { - Prestige products } \\
\text { - Infrequent } \\
\text { - Require a higher level of interest and } \\
\text { knowledge } \\
\text { - Strongly relate to the person's self- } \\
\text { concept }\end{array}$ & $\begin{array}{l}\text { - Car insurance } \\
\text { - Car financing } \\
\text { - Child day- } \\
\text { care services } \\
\text { - Accounting } \\
\text { - } \text { services } \\
\text { - Estate agents } \\
\text { - Gold/silver }\end{array}$ \\
\hline $\begin{array}{l}\text { Phau and Poon, } \\
2000\end{array}$ & $\begin{array}{ll}\text { - } & \text { Expensive } \\
\text { - } & \text { Infrequent } \\
\text { - } & \text { Intangible } \\
\text { - } & \text { High differentiation }\end{array}$ & $\begin{array}{l}\text { bars } \\
\text { - Jewellery }\end{array}$ \\
\hline
\end{tabular}


Table 2: Coding hierarchy

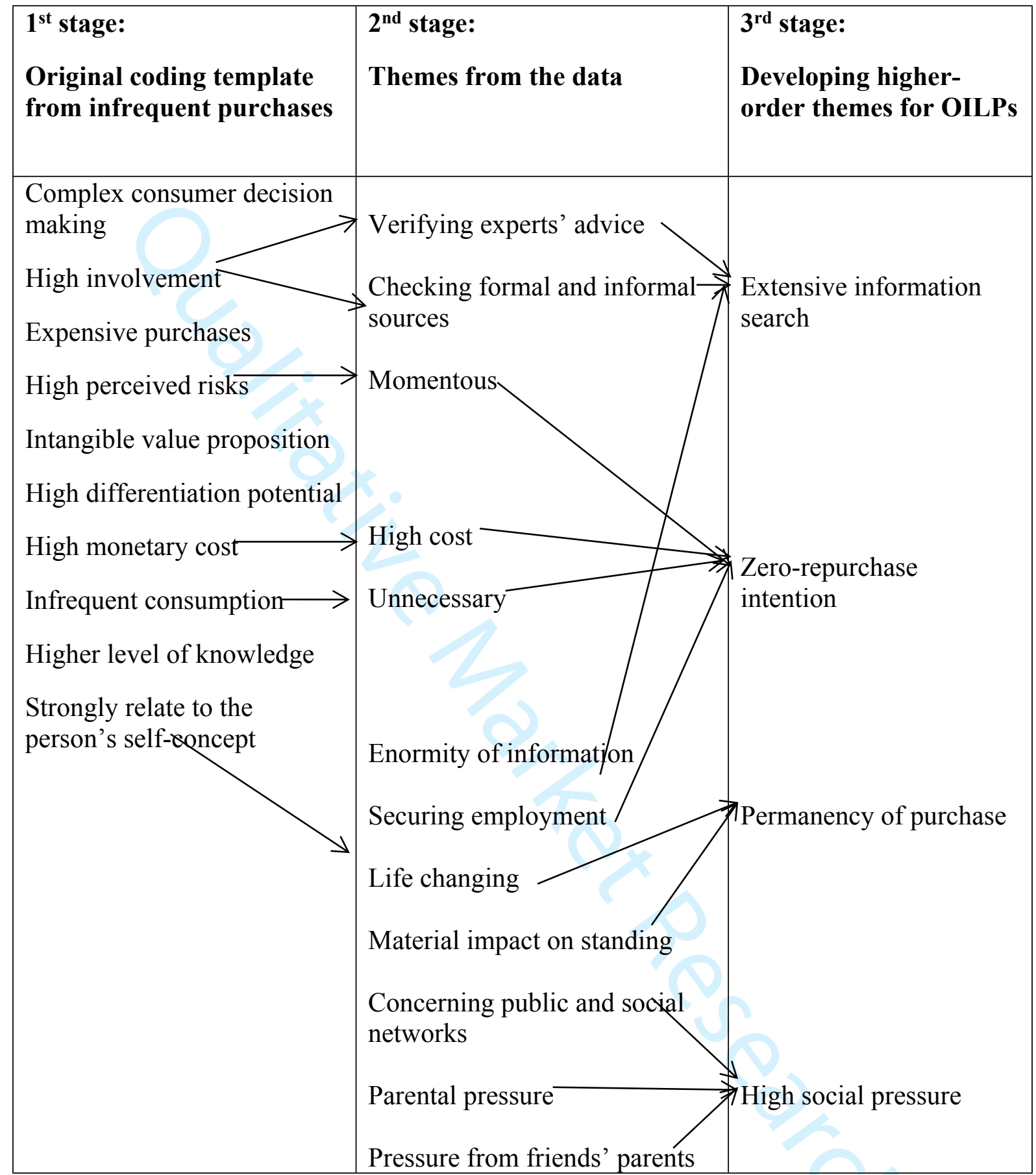


Table 3: Comparison between infrequent and once-in-a-lifetime purchases

\begin{tabular}{|c|c|c|}
\hline & Infrequent purchases & $\begin{array}{c}\text { Once-in-a-lifetime } \\
\text { purchases }\end{array}$ \\
\hline Price & \multicolumn{2}{|c|}{ Expensive } \\
\hline Intangibility & \multicolumn{2}{|c|}{ High } \\
\hline Product differentiation & \multicolumn{2}{|c|}{ High } \\
\hline Frequency of purchase & $\begin{array}{c}\text { Infrequent, but could } \\
\text { become frequent over time }\end{array}$ & $\begin{array}{l}\text { Once only in life (for most } \\
\text { consumers) }\end{array}$ \\
\hline Repurchase intention & Yes, at some point & Zero \\
\hline Social pressure & Low & Very high \\
\hline Impact of the purchase & Limited & Forever \\
\hline Decision-making time & Shorter time length & Longer time length \\
\hline Decision waves & Few & Several waves of screening \\
\hline Perceived risk & High & Very high \\
\hline Involvement & High & Very high \\
\hline $\begin{array}{c}\text { Prior product knowledge } \\
\text { and understanding }\end{array}$ & $\begin{array}{l}\text { Limited, but will increase } \\
\text { over time }\end{array}$ & $\begin{array}{l}\text { Limited, but will become } \\
\text { experienced after }\end{array}$ \\
\hline Need for assurance & Moderate & Very high \\
\hline Typical examples & $\begin{array}{l}\text { Childcare providers, TV } \\
\text { repair services, life } \\
\text { insurance, estate agents, } \\
\text { accounting services, legal } \\
\text { services }\end{array}$ & $\begin{array}{c}\text { Engagement rings, HE } \\
\text { services, honeymoon } \\
\text { packages, wedding } \\
\text { photography and other } \\
\text { wedding-related services }\end{array}$ \\
\hline
\end{tabular}


Appendix 1: Profile of Taiwanese participants (Phase One)

\begin{tabular}{|c|c|c|c|}
\hline & Gender & Age & Financial support \\
\hline Student 1 & Male & 26 & Family \\
\hline Student 2 & Male & 27 & Family \\
\hline Student 3 & Female & 28 & Family \\
\hline Student 4 & Female & 29 & Self and family \\
\hline Student 5 & Male & 30 & Self \\
\hline Student 6 & Female & 26 & Family \\
\hline Student 7 & Female & 31 & Self \\
\hline Student 8 & Female & 27 & Family \\
\hline Student 9 & Female & 28 & Self \\
\hline Student 10 & Male & 34 & Self \\
\hline Student 11 & Female & 26 & Self \\
\hline Student 12 & Male & 26 & Family and self \\
\hline Student 13 & Male & 22 & Self \\
\hline Student 14 & Female & 28 & Self \\
\hline Student 15 & Female & 26 & Family \\
\hline Student 16 & Female & 27 & Family \\
\hline Student 17 & Female & 26 & Family \\
\hline Student 18 & Male & 25 & Family \\
\hline Student 19 & Male & 29 & Family \\
\hline Student 20 & Male & 29 & Family \\
\hline Student 21 & Male & 26 & Family \\
\hline Student 22 & Male & 36 & Self \\
\hline Student 23 & Male & 27 & Self and family \\
\hline Student 24 & Female & 32 & Self \\
\hline
\end{tabular}




\begin{tabular}{|l|l|l|l|}
\hline Student 25 & Female & 26 & Family \\
\hline Student 26 & Female & 25 & Family \\
\hline Student 27 & Male & 37 & Self \\
\hline Student 28 & Male & 24 & Family \\
\hline Student 29 & Male & 24 & Family \\
\hline Student 30 & Male & 23 & Family \\
\hline Student 31 & Male & 24 & Family and self \\
\hline Student 32 & Male & 23 & Family \\
\hline Student 33 & Male & 23 & Family \\
\hline Student 34 & Female & 23 & Family \\
\hline
\end{tabular}

Appendix 2: Profile of Chinese participants (Phase Two)

\begin{tabular}{|l|l|l|l|}
\hline & Gender & Age & Financial support \\
\hline Student 35 & Female & 25 & Family \\
\hline Student 36 & Male & 24 & Family \\
\hline Student 37 & Male & 22 & Family \\
\hline Student 38 & Male & 25 & Self and family \\
\hline Student 39 & Male & 23 & Family \\
\hline Student 40 & Female & 23 & Family \\
\hline Student 41 & Female & 25 & Family \\
\hline Student 42 & Male & 30 & Self \\
\hline Student 43 & Male & 23 & Family \\
\hline Student 44 & Female & 22 & Family \\
\hline Student 45 & Female & 26 & Self and family \\
\hline
\end{tabular}

